\title{
Importance and abundance of the recently established species Coscinodiscus wailesii Gran \& Angst in the German Bight
}

\author{
H.-J. Rick ${ }^{1}$ \& C.-D. Dürselen ${ }^{2 *}$ \\ ${ }^{1}$ Institut für Chemie und Biologie des Meeres (ICBM), Carl-von-Ossietzky-Universität \\ Oldenburg; Carl-von-Ossietzky-Straße 9-11, D-26111 Oldenburg, Germany \\ ${ }^{2}$ Institut für Biologie I, Lehr- und Forschungsgebiet Ökologie des Bodens, Rheinisch \\ Westfälische Technische Hochschule Aachen; Worringerweg, D-52056 Aachen, Germany
}

\begin{abstract}
Grids of 17 to 50 stations in the German Bight were sampled 18 times within the framework of the multidisciplinary programmes ZISCH and PRISMA in winter and spring of 1988/89 and from April 1991-April 1992. The frequent abundance of Coscinodiscus wailesii Gran \& Angst, a recently established large diatom, was noteworthy, as it dominated the phytoplankton biomass over long periods (e.g. 12/88-3/89 and 8/91-11/91). The bulk of the phytoplankton carbon during these periods (up to $90 \%$ ) could be attributed to this species. Blooms of Coscinodiscus wailesii producing up to $1400 \mu \mathrm{g}$ carbon $\mathrm{l}^{-1}$, were recorded in early spring of 1989 and autumn of 1991 . The potential consequences for the whole ecosystem refer to the huge size of this organism, which may cause reduced exploitation of its primary production by native consumers. Furthermore, sedimentation and remineralisation processes may be affected. For $C$. wailesii, a doubling of biomass in $70 \mathrm{~h}$ could be estimated on the basis of data from four successive surveys in 1991. Results from laboratory cultures under comparable conditions confirm this rate. In the survey area, no increase in biomass was recorded for the related Coscinodiscus granii Gough, although there was sufficient silicate supply for growth. Field data showed 8-10 times lower copper and 10-20 times lower cadmium and zinc accumulation in $C$. wailesii, compared to concentrations found in native phytoplankton species. Subsequent laboratory tests suggested that one reason for the remarkable success of $C$. wailesii, mainly in inshore regions, may be derived from its tolerance of higher doses of heavy metals due to very low sorption.
\end{abstract}

\section{INTRODUCTION}

The spreading of plankton species in different parts of the world oceans is not a new phenomenon. Spreading may be caused by ocean currents transporting drifting organisms, by merchant ships transferring ballast water (Gerlach, 1992) or by stocking the seas with living organisms native to other countries (Rince \& Plaumier, 1986).

For the North Sea, a number of examples of new arrivals in the phytoplankton are known, e.g. Odontella (Biddulphia) sinensis Grev. (Ostenfeld, 1908, 1909); Thalassiosira punctigera Castr. (Kat, 1982); Thalassiosira hendeyi Hasle \& Fryxell (Rick, 1990) Corethron criophilum, Stephanopyxis palmeriana (Drebes, 1991); Gyrodinium aureolum

\footnotetext{
" Present address as ${ }^{1}$
} 
Hulburt (Tangen, 1977); Pleurosigma planktonicum Simonsen (Boalch \& Harbour, 1977 a); Coscinodiscus wailesii Gran \& Angst (Boalch \& Harbour, 1977b; Robinson et al., 1980; Rince \& Plaumier, 1986). In most cases these new arrivals are not stock-forming in their new distribution areas, with the exception of the mentioned dinoflagellate, and the large centric diatoms Odontella sinensis and Coscinodiscus wailesii. They may have a strong impact on the structure of the pelagic ecosystem by partly replacing native populations during certain seasons.

Coscinodiscus wailesii shows a worldwide distribution. A review is given in Rince \& Plaumier (1986). It is found both in the Pacific (Gran \& Angst, 1931; Cupp, 1943; Gotelli, 1971; Guo Yujie, 1981; Manabe \& Ishio, 1991) and in the Atlantic Ocean (Patten et al., 1963; Mahoney \& Steimle, 1980; Marshall, 1984). In 1977 the species was first recognized in waters off the southern coast of England waters (Boalch \& Harbour, 1977a). Since then it has spread through the whole North Sea.

\section{MATERIAL AND METHODS}

Distribution and abundance of Coscinodiscus wailesii Gran \& Angst was analyzed in the North Sea within the project studies ZISCH I (1986/87: circulation and Transfer of Pollutants in the North Sea), ZISCH II (1988/89: Circulation and Transfer of Pollutants in the German Bight), PRISMA (1991/92: Transport, Transfer and Transformation Processes in the German Bight), TUVAS (1991/92: Transport, Conversion and Variability of Pollutants and Nutrients in the German Bight), and OPTINOM (1991/92: Improvement of the North Sea Monitoring). Additional data were obtained during a ten year period of studies (1982-1992) in the outer Scheldt estuary near Breskens (The Netherlands).

During the ZISCH I programme, the phytoplankton was analyzed in the entire North Sea at 131 stations. In the following 3 years (11/88-4/92) the German Bight was sampled with 18 grids of $17-51$ stations. These studies concentrated on the measurement of the heavy metal content in the phytoplankton and on the recording of the species composition of the primary producers.

Samples for phytoplankton analysis were collected at 2 to 4 different depths with rosette samplers (CTD), fixed with buffered formol and processed by the technique of the inverted microscope within 3 months after sampling. Cell volume and carbon content of the cells were calculated, based on quantitative data of plankton analysis according to Rick (1990) and Strickland \& Parsons (1972).

To avoid metal contamination from the research vessel, samples for heavy metal determination of the plankton were taken by rubber dinghy in the surface layer by using a modified (no metal parts) plankton net ( $55 \mu \mathrm{m}$ mesh size). Direct microscopic control of these samples followed, in order to estimate the percentage of phytoplankton content. An aliquot of each net sample was fixed with buffered formol for subsequent quantitative plankton analysis.

The cells were concentrated on Sartorius cellulose nitrate filters (pore size $0.2 \mu \mathrm{m}$ ) for trace metal analysis, if the phytoplankton content consisted of over $90 \%$ of the entire seston. For purification procedure of filters see Mart (1979a).

Heavy metal analysis was carried out using the Differential Pulse Anodic Stripping Voltammetry method (DPASV; Metrohm VA Processor 646 and VA Elektrode 647) after 
conditioning the filter samples in an oxygen plasma processor (Plasma Technics model $200 \mathrm{G}$ ). For prevention of contamination and other risks in accuracy in voltametric trace metal analysis see Mart (1979a, b, c, 1982) and Mart et al. (1980).

Additional laboratory data were obtained using batch and semicontinuous cultures of Coscinodiscus wailesii. The clone used was isolated from a net plankton sample taken from the outer Scheldt estuary near Breskens (The Netherlands) in February 1991. The non-axenic unialgal stock cultures were kept both in 20-ml Scinti-Vials and 1-1 Duranbottles at $12^{\circ} \mathrm{C}$ and a quantum scalar irradiance of $18 \mu \mathrm{E} \mathrm{m}^{-2} \mathrm{~s}^{-1}$ (cool white fluorescent tubes, Phillips TLM $33 \mathrm{RS} / 65$ ) in a 12:12 h light/dark cycle. Experiments were carried out in Celstir bottles (Zinsser) at the same light/dark cycle and a light level of $50 \mu \mathrm{E} \mathrm{m} \mathrm{m}^{-2}$ $\mathrm{s}^{-1}$ (LI-COR LI-185B Quantummeter with LI-190SB Quantum sensor). The cultures were stirred using a Wheaton-Biostir-6 system (Zinsser). Dilution rates varied from 0.2 to 0.5 day $^{-1}$.

Media were prepared using $0.2-\mu \mathrm{m}$ membrane-filtered North Sea water from the German Bight (4/91). The salinity ranged from 31 to $32 \%$. The media were enriched with nutrients according to Von Stosch \& Drebes (1964). $\mathrm{N}$ and $\mathrm{P}$ were added at $0.1, \mathrm{Si}$ at 1.0 strength, specified in $\mu \mathrm{mol} \mathrm{dm}{ }^{-3}$ : N: $56, \mathrm{P}: 30$, Si: 35 , Fe: $1.0, \mathrm{Mn}: 0.1$. The vitamins $\mathrm{B}_{12}$, biotine, and thiamine were added to final concentrations of $50 \mu \mathrm{g} \mathrm{dm}^{-3}$. In order not to change the complexing capacity of the seawater, there was no addition of chelating agents. Relative complexing capacity (RCC) was measured by a voltamperometric method using lead as indicator metal (complexing time $10 \mathrm{~min} ; 0.5 \mu \mathrm{g} \mathrm{Pb} \mathrm{dm}{ }^{-3} 10 \mathrm{~min}$ $\triangleq \mathrm{RCC}=1$; Rick, 1990).

The treatment of samples for heavy metal analysis of the cultured algae was the same as in field samples. Heavy metal contents of the media were analyzed using the DPASV method after UV photolysis according to Mart (1979c). Bioconcentration factors (BCF) were calculated based on the metal concentration both in the medium and the algae.

Doubling times were calculated from changes in cell number during exponential growth.

\section{RESULTS}

\section{North Sea}

Figure 1 displays the distribution of Coscinodiscus wailesii during the ZISCH summer cruise in May-June 1986, as well as the observations of some other authors. Only 10 of the 131 stations sampled showed an occurrence of this species. It was found mainly in the northern parts of the sampling area near the Orkney, Shetland, and Faroe islands. C. wailesii occurred in the southern part of the North Sea only at two stations in the most outer part of the German Bight. During the ZISCH summer campaign, the species was not stock-forming. It was found in a salinity and temperature range from $34.41-35.28 \% \mathrm{~S}$ and $6.84-8.92^{\circ} \mathrm{C}$, respectively.

\section{Scheldt estuary}

Since the early 'eighties, the species composition of the phytoplankton in the outer Scheldt estuary was analyzed 50 times in 10 years. There, Coscinodiscus wailesii was first 


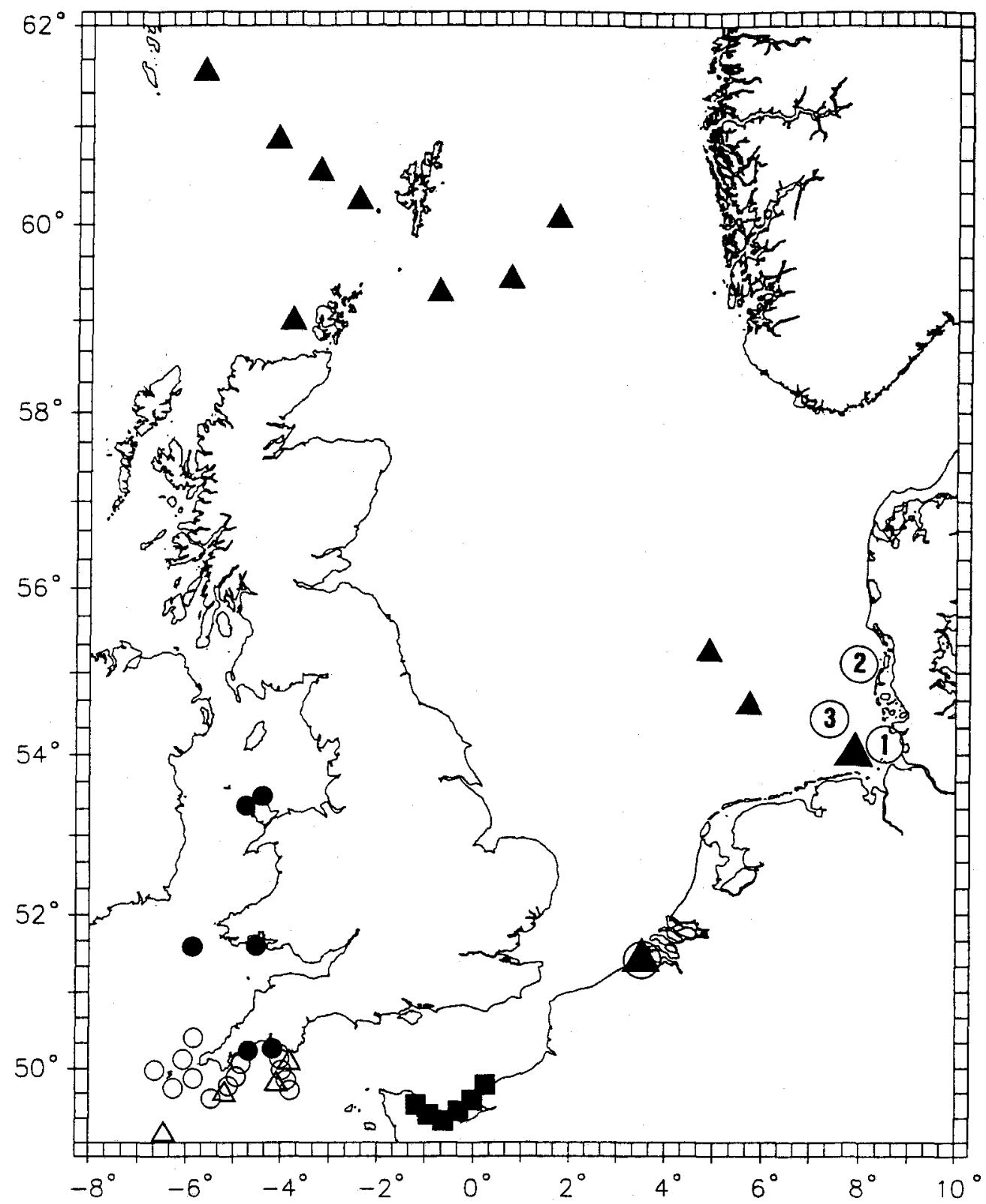

Fig. 1. Distribution pattern of Coscinodiscus wailesii Gran \& Angst in the North Sea and adjacent waters. This study's data and the data of other authors are given in one general map. Small filled triangles: ZISCH campaign May-June 1986, Rick (1990); large filled triangle: this study; circled triangle: 10 year period (1982-1992), Scheldt estuary; filled squares: Rince \& Plaumier (1986); small open circles: Robinson et al. (1980); open triangles: Boalch \& Harbour (1977a); open circle 1: Gillbricht in Rince \& Plaumier (1986); open circle 2: Drebes in Rince \& Plaumier (1986); open circle 3: 
recognized in 1982. More than $50 \%$ of the samples contained $C$. wailesii. It was most abundant from September to March in salinity and temperature ranges of 24-32\% S and $0-20^{\circ} \mathrm{C}$. No proof exists of its occurrence in early summer (June/July). In most cases, we found $C$. wailesii accompanied by Thalassiosira punctigera Castr. and Thalassiosira hendeyi Hasle \& Fryxell, two other introduced species.

\section{German Bight}

Table 1 shows the abundance and biomass development of $C$. wailesii during two campaigns (18 cruises) of investigation (1: 11/88-5/89; 2: 4/91-4/92) in the German Bight. Figures 2-7 describe the accompanying spatial distributions. The data point out that Coscinodiscus wailesii has established itself in the German Bight area during the last decade. In some periods (11/88-3/89 and 8/91-10/91) more than $90 \%$ of the phytoplank-

Table 1. Abundance and biomass of Coscinodiscus wailesii in the German Bight during the programs ZISCH II, PRISMA, TUVAS and OPTINOM. The campaign period, the number of the sampled stations, the percentage of stations in which $C$. wailesii was stock-forming and mean/ maximum biomass levels in carbon units for the whole water column are given

\begin{tabular}{|c|c|c|c|c|}
\hline \multirow{2}{*}{ Cruise } & \multirow{2}{*}{$\begin{array}{l}\text { Sampled } \\
\text { stations }\end{array}$} & \multirow{2}{*}{$\begin{array}{l}\text { Percent- } \\
\text { age }\end{array}$} & \multicolumn{2}{|c|}{ Biomass (mg C m${ }^{-3}$ ) } \\
\hline & & & Max. • & Mean $\cdots$ \\
\hline \multicolumn{5}{|c|}{ ZISCH II } \\
\hline $11 / 88$ & 23 & 39 & 314 & 175.9 \\
\hline $12 / 88$ & 23 & 22 & 142 & 69.1 \\
\hline $01 / 89$ & 17 & 71 & 170 & 45.9 \\
\hline $02 / 89$ & 17 & 41 & 382 & 141.0 \\
\hline $03 / 89$ & 8 & 63 & 1270 & 475.3 \\
\hline $04 / 89$ & 17 & 29 & 178 & 92.7 \\
\hline $05 / 89$ & 20 & 20 & 357 & 113.6 \\
\hline \multicolumn{5}{|l|}{ PRISMA } \\
\hline $04 / 91$ & 50 & 0 & 0 & 0 \\
\hline $08 / 91-1$ & 51 & 52 & 1004 & 142.3 \\
\hline $08 / 91-2$ & 33 & 48 & 550 & 212.3 \\
\hline $08 / 91-3$ & 44 & 34 & 812 & 179.2 \\
\hline 08/91-4 & 42 & 47 & 1705 & 348.4 \\
\hline $08 / 91-5$ & 51 & 41 & 1325 & 482.6 \\
\hline \multicolumn{5}{|c|}{ TUVAS-OPTINOM } \\
\hline 09/91 & 20 & 85 & 421 & 220.0 \\
\hline $10 / 91$ & 20 & 80 & 445 & 131.1 \\
\hline $01 / 92$ & 18 & 44 & 29 & 14.0 \\
\hline $03 / 92$ & 18 & 83 & 210 & 80.2 \\
\hline \multicolumn{5}{|l|}{ PRISMA } \\
\hline $04 / 92$ & 42 & 59 & 551 & 96.4 \\
\hline \multicolumn{5}{|c|}{$\begin{array}{l}\therefore \text { percentage of the sampled stations where Coscinodiscus wailesii was stock-forming. } \\
\text { maximum carbon content of Coscinodiscus wailesii }\left(\mathrm{mg} \mathrm{C} \mathrm{m}^{-3}\right) \text { for this particular cruise. } \\
\text { mean carbon content of Coscinodiscus wailesii }\left(\mathrm{mg} \mathrm{C} \mathrm{m}^{-3}\right) \text { at each station where this species } \\
\text { was stock-forming. }\end{array}$} \\
\hline
\end{tabular}




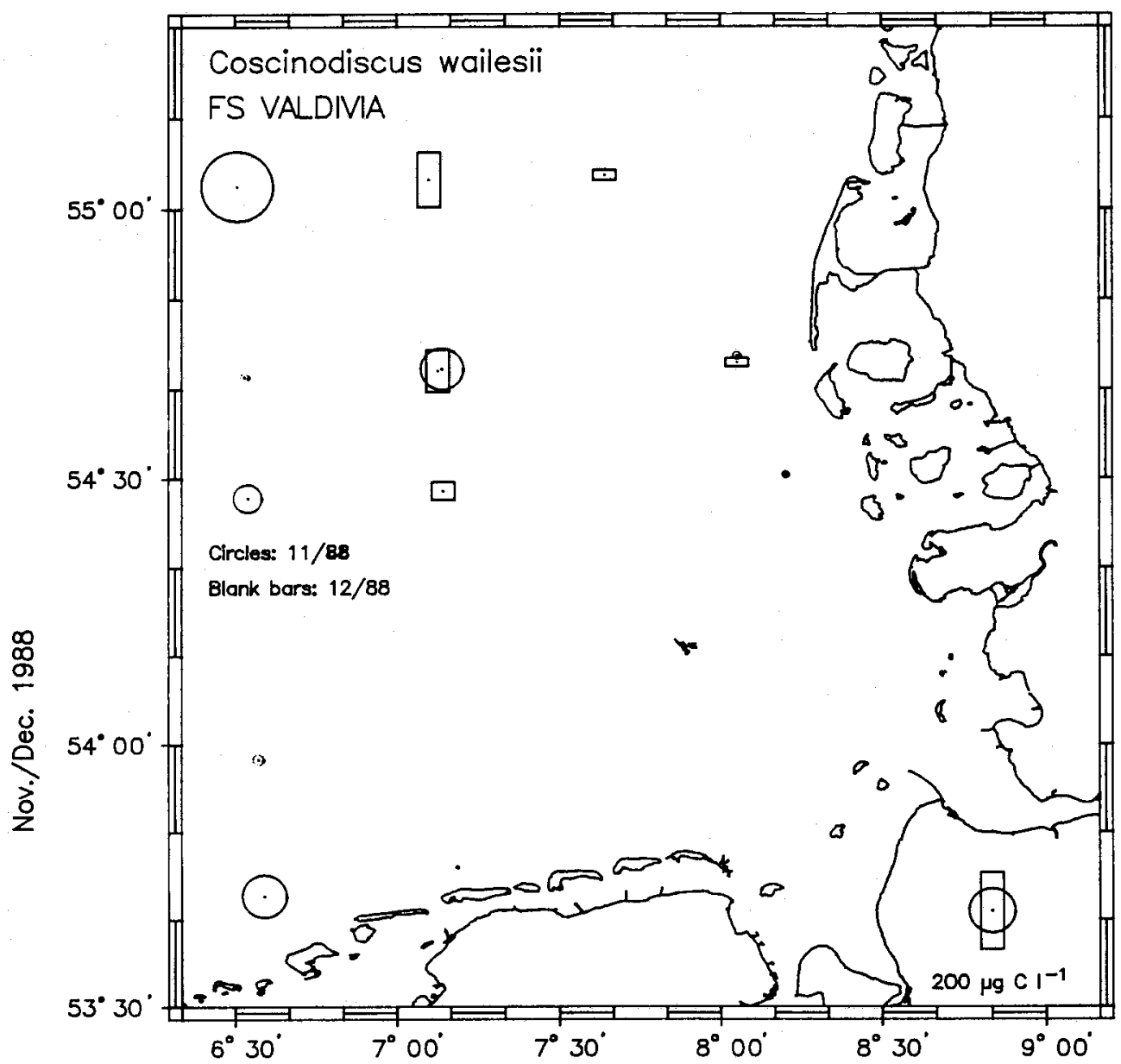

Fig. 2. Spatial distribution and biomass of Coscinodiscus wailesii in the German Bight. Results of two winter cruises in November and December 1988. The biomass data are given as mean carbon values $\left(\mu \mathrm{g} \mathrm{C} \mathrm{dm}{ }^{-3}\right)$ for the upper layer $(0-20 \mathrm{~m})$ of the water column. Symbol size compares to the biomass value (see legend lower right)

ton biomass was bound in this species. We found C. wailesii in a temperature and salinity range from $2.0-17.0^{\circ} \mathrm{C}$ and $27-34 \% \mathrm{~S}$, respectively.

In winter, the species was merely present near the outer borders of the German Bight with low biomass levels (Figs 2, 5, 7). Spring showed a richer abundance in the western region; the species was absent in the area of the Elbe River plume (Figs 4, 6, 7). In summer and early autumn, there were records of $C$. wailesii in the coastal and eastern part of the German Bight (Fig. 5), while it was more abundant at the western and northern borders of the survey region in late autumn (Fig. 5).

During the PRISMA programme in August 1991, four successive grids of 40 to 50 stations were sampled in the German Bight. Each station was resampled in a time course of $72 \mathrm{~h}$. The data of this survey are shown as mean values in Table 1. C. wailesii was most 


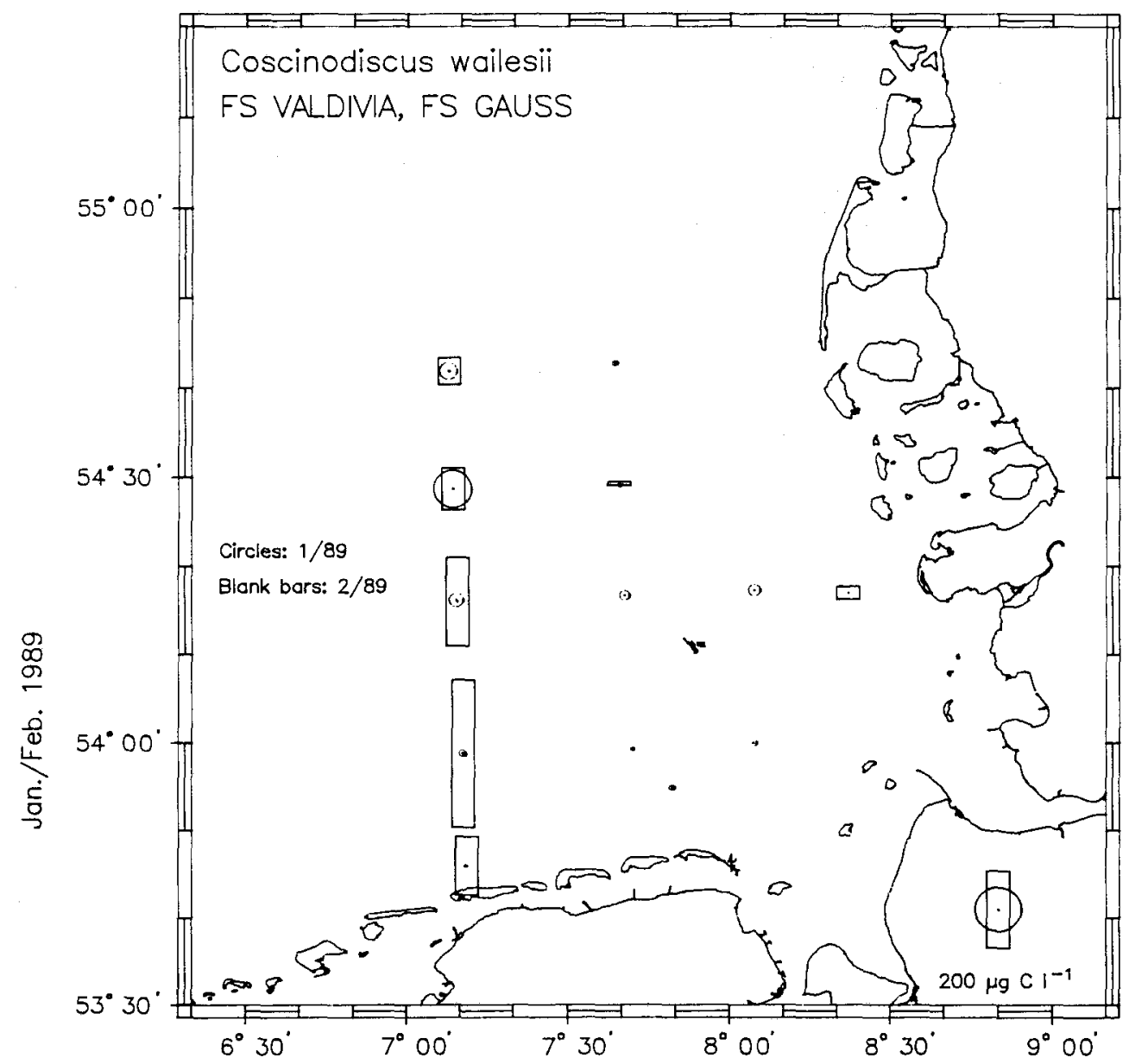

Fig. 3. Spatial distribution and biomass of Coscinodiscus wailesii in the German Bight. Results of two winter cruises in January and February 1989. The biomass data are given as mean carbon values ( $\mu \mathrm{g}$ $C \mathrm{dm}^{-3}$ ) for the upper layer $(0-20 \mathrm{~m})$ of the water column. Symbol size compares to the biomass value (see legend lower right)

abundant in the coastal area of the German Bight $\left(8.10^{\circ}-7.5^{\circ} \mathrm{E}, 54.13^{\circ}-54.43^{\circ} \mathrm{N}, 9\right.$ stations) with increasing biomass during the survey period (15th-29th August). It was accompanied by the native species Coscinodiscus granii Gough. For the area mentioned, mean biomass doubling-times for both species were calculated on the basis of the integrated biomass values from the upper layer of the water column $(0-20 \mathrm{~m})$. No significant growth of $C$. granii was determined while $C$. wailesii showed doubling-times of $70 \mathrm{~h}$.

Figure 7 shows the spatial distribution and biomass of the related species Coscinodiscus wailesii and Coscinodiscus concinnus W. Smith during the PRISMA spring campaign in April 1992. Both species have identical distribution patterns, but the areas of maximum 


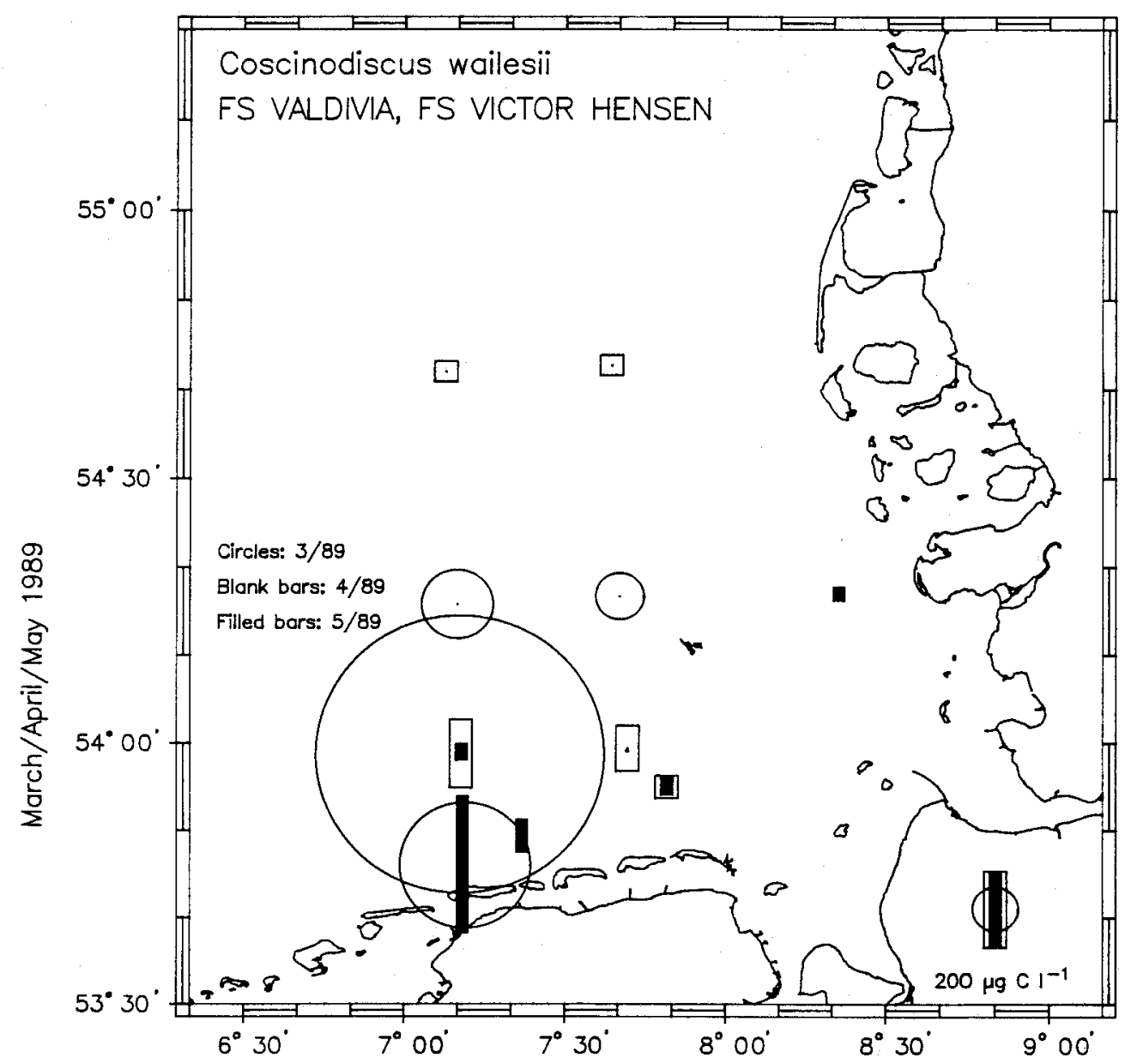

Fig. 4. Spatial distribution and biomass of Coscinodiscus wailesii in the German Bight. Results of three spring cruises in March. April and May 1989. The biomass data are given as mean carbon values $\left(\mu \mathrm{g} \mathrm{C} \mathrm{dm}^{-3}\right)$ for the upper layer $(0-20 \mathrm{~m})$ of the water column. Symbol size compares to the biomass value (see legend lower right)

cell numbers differ. C. concinnus exceeds $C$. wailesii in the outer bight, while $C$. wailesii is dominant in the East Frisian coastal waters.

\section{Bioconcentration of trace metals}

Field data concerning bioconcentration factors of trace metals in natural phytoplankton assemblages in the German Bight suggest that communities dominated by Coscinodiscus wailesii show less accumulation of zinc and copper than communities dominated by other species (Table 2; Figs 8,9 ). The same can be found for the accumulation for lead and cadmium (Figs 10,11). Only at three stations $(19,31,40$-compare Figs 8-11) 


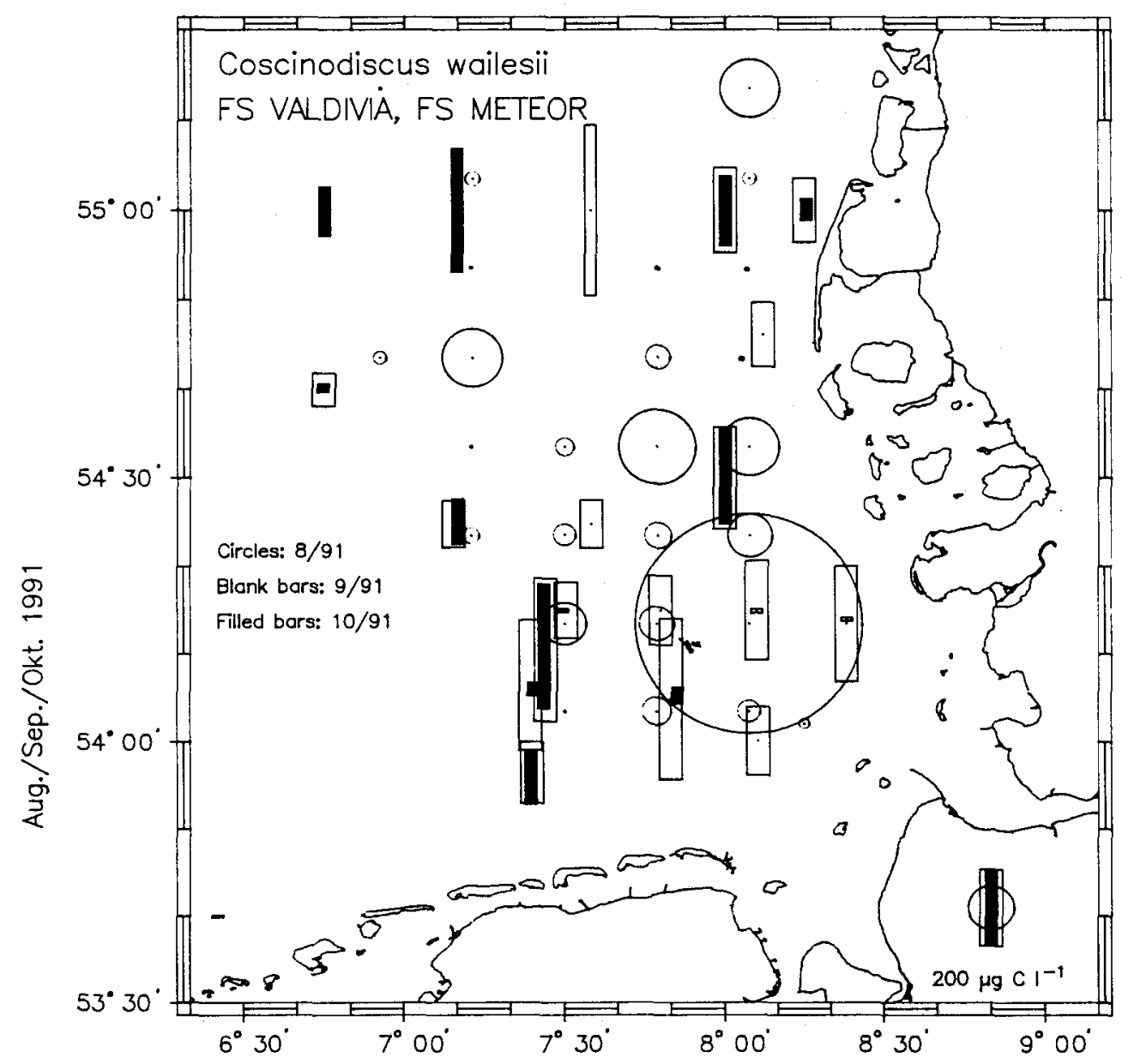

Fig. 5. Spatial distribution and biomass of Coscinodiscus wailesii in the German Bight. Results of three cruises in summer and autumn (August 1991, September 1991, October 1991). The biomass data are given as mean carbon values $\left(\mu \mathrm{g} \mathrm{C} \mathrm{dm}^{-3}\right)$ for the upper layer $(0-20 \mathrm{~m})$ of the water column. Symbol size compares to the biomass value (see legend lower right)

where $C$. wailesii was abundant, were relatively high metal contents $(\mathrm{Zn}, \mathrm{Cu}, \mathrm{Cd})$ in the plankton found. They were located at the outer distribution border of $C$. wailesii, where this species was mainly accompanied by the centric diatom Rhizosolenia shrubsolei Cleve.

The results of subsequent laboratory experiments concerning the bioconcentration of zinc and copper in C. wailesii are shown in Table 4.

\section{DISCUSSION}

Figure 1 shows the distribution of $C$. wailesii Gran \& Angst in the North Sea and adjacent waters. Our own results and the data of other authors are shown in one general 
Table 2. Bioconcentration factors (BCF) of zinc and copper in natural phytoplankton populations (August 1991, German Bight). The relative complexing capacity (RCC) of the seawater varied from 0.8 to 1.5 during the cruise. BCF, zinc and copper content of the seawater, standard deviations, minimum and maximum value are given

\begin{tabular}{|lcl|}
\hline Mean Zn content, water: & $472 \pm 237$ & $\mathrm{ng} \mathrm{Zn} \mathrm{kg}^{-1}$ \\
Minimum value: & 232 & $\mathrm{ng} \mathrm{Zn} \mathrm{kg}^{-1}$ \\
Maximum value: & 1025 & $\mathrm{ng} \mathrm{Zn} \mathrm{kg}^{-1}$ \\
\hline
\end{tabular}

\begin{tabular}{|lccccc|}
\hline Phytoplankton & $\begin{array}{c}\text { BCF } \\
\text { zinc }\end{array}$ & $\begin{array}{l}\text { Standard } \\
\text { deviation }\end{array}$ & $\begin{array}{c}\text { Min. } \\
\text { value }\end{array}$ & $\begin{array}{l}\text { Max. } \\
\text { value }\end{array}$ & $\mathrm{n}$ \\
\hline $\begin{array}{l}\text { C. wailesii } \\
\text { abundant } \\
\begin{array}{l}\text { Other species } \\
\text { abundant }\end{array}\end{array}$ & 29300 & 25000 & 7300 & 62200 & 12 \\
\hline
\end{tabular}

\begin{tabular}{|lll|}
\hline Mean Cu content, water: & $390 \pm 74$ & $\mathrm{ng} \mathrm{Cu} \mathrm{kg}^{-1}$ \\
Minimum value: & 306 & $\mathrm{ng} \mathrm{Cu} \mathrm{kg}^{-1}$ \\
Maximum value: & 624 & $\mathrm{ng} \mathrm{Cu} \mathrm{kg}^{-1}$
\end{tabular}

\begin{tabular}{|lccccc|}
\hline Phytoplankton & $\begin{array}{c}\text { BCF } \\
\text { copper }\end{array}$ & $\begin{array}{l}\text { Standard } \\
\text { deviation }\end{array}$ & $\begin{array}{c}\text { Min. } \\
\text { value }\end{array}$ & $\begin{array}{c}\text { Max. } \\
\text { value }\end{array}$ & $\mathrm{n}$ \\
\hline $\begin{array}{l}\text { C. wailesii } \\
\text { abundant } \\
\begin{array}{l}\text { Other species } \\
\text { abundant }\end{array}\end{array}$ & 4430 & 3790 & 980 & 11460 & 12 \\
\hline
\end{tabular}

map. C. wailesii was discovered in 1977 by Boalch \& Harbour (1977a) in the Celtic Sea, the English Channel (Rince \& Plaumier, 1986) and the southern part of the Irish Sea (Robinson et al., 1980). Simonsen (in Rince \& Plaumier, 1986) stated that the species occurs at nearly all North Sea coastlines.

The data of Boalch \& Harbour (1977a) and Robinson et al. (1980), who recorded high biomasses of $C$. wailesii in winter and spring in inshore waters, while cell numbers declined towards May, correspond well with our findings in the Scheldt area and the German Bight.

The observed wide range of salinity and temperature for species occurrence confirms the reports from Rince \& Plaumier (1986), who stated that $C$. wailesii occurred in open ocean, as well as in estuary and inshore, regions.

During the 'eighties, $C$. wailesii became an important member of the phytoplankton in the German Bight (Gillbricht and Drebes in Rince \& Plaumier 1986; Hesse, 1988; 
Table 3. Bioconcentration factors (BCF) for the trace metals copper and zinc. Coscinodiscus wailesii in semicontinuous cultures (dilution rate $0.5-0.2 \mathrm{~d}^{-1}, 12{ }^{\circ} \mathrm{C}$, light dark cycle: $12: 12 \mathrm{~h} ; 50 \mu \mathrm{E} \mathrm{m} \mathrm{m}^{-2} \mathrm{~s}^{-1}$ ). Mean biomass doubling-times, ranges of the zinc, copper content, and RCC (relative complexing capacity) of the media are given. $n=$ number of data points

\begin{tabular}{lll}
\hline Range of Cu content (medium): & $1-8$ & $\mu \mathrm{g} \mathrm{Cu} \mathrm{kg}^{-1}$ \\
Range of Zn content (medium): & $3-5$ & $\mu \mathrm{g} \mathrm{Zn} \mathrm{kg}^{-1}$ \\
RCC: & $0.8 \triangleq 0.4$ & $\mu \mathrm{g} \mathrm{Pb} \mathrm{kg}$ \\
Doubling-time: & $107.9 \pm 37.2$ &
\end{tabular}

\begin{tabular}{|lccccc|}
\hline Trace metals & BCF & $\begin{array}{c}\text { Standard } \\
\text { deviation }\end{array}$ & $\begin{array}{c}\text { Min. } \\
\text { value }\end{array}$ & $\begin{array}{c}\text { Max. } \\
\text { value }\end{array}$ & $n$ \\
\hline Copper & 2700 & 910 & 1000 & 4790 & 65 \\
Zinc & 5890 & 1660 & 2200 & 9710 & 67 \\
\hline
\end{tabular}

Table 4. Bioconcentration factors $(\mathrm{BCF})$ and volume-related metal content of various North Sea phytoplankton species in semicontinuous cultures with literature references

\begin{tabular}{|c|c|c|c|c|c|c|c|}
\hline Species & $\begin{array}{l}\text { Content } \\
\text { medium } \\
\left(\mathrm{ng} \mathrm{kg} \mathrm{kg}^{-1}\right)\end{array}$ & $\begin{array}{c}\text { COPPER } \\
\text { Content } \\
\text { cells } \\
\left(10^{-10}\right. \\
\left.\mathrm{ng} \mu \mathrm{m}^{-3}\right)\end{array}$ & $\mathrm{BCF}$ & $\begin{array}{l}\text { Content } \\
\text { medium } \\
\left.(\mathrm{ng} \mathrm{kg})^{-1}\right)\end{array}$ & $\begin{array}{c}\text { ZIN } \\
\text { Content } \\
\text { cells } \\
\left(10^{-10}\right. \\
\left.\text { ng } \mu^{-3}\right)\end{array}$ & $\mathrm{BCF}$ & Author \\
\hline $\begin{array}{l}\text { Scrippsiella } \\
\text { trochoidea }\end{array}$ & 450 & $\begin{array}{r}50 \\
\pm 14\end{array}$ & $\begin{array}{r}11200 \\
\pm \quad 3100\end{array}$ & 6300 & $\begin{array}{r}450 \\
\pm \quad 80\end{array}$ & $\begin{array}{r}7070 \\
\pm 1260\end{array}$ & $\begin{array}{l}\text { Corves } \\
(1992)\end{array}$ \\
\hline $\begin{array}{l}\text { Gyrodinium } \\
\text { aureolum }\end{array}$ & 620 & $\begin{array}{r}120 \\
\pm \quad 10\end{array}$ & $\begin{array}{r}19350 \\
\pm \quad 1600\end{array}$ & 5800 & 460 & 8000 & $\begin{array}{l}\text { Rick } \\
(1990)\end{array}$ \\
\hline $\begin{array}{l}\text { Phaeocystis } \\
\text { globosa }\end{array}$ & 1130 & 185 & 16390 & 9500 & $\begin{array}{r}1300 \\
+\quad 20\end{array}$ & 13700 & $\begin{array}{l}\text { Rick } \\
(1990)\end{array}$ \\
\hline $\begin{array}{l}\text { Micromonas } \\
\text { pusilla }\end{array}$ & 3800 & $\begin{array}{r}830 \\
+195\end{array}$ & $\begin{array}{r}21800 \\
\pm \quad 5100\end{array}$ & 14600 & $\begin{array}{r}325 \\
+180\end{array}$ & $\begin{array}{r}2200 \\
\pm 1200\end{array}$ & $\begin{array}{l}\text { Rick } \\
(1990)\end{array}$ \\
\hline $\begin{array}{l}\text { Thalassiosira } \\
\text { rotula }\end{array}$ & 480 & $\begin{array}{r}66 \\
\pm \quad 4\end{array}$ & $\begin{array}{r}13700 \\
\pm \quad 830\end{array}$ & 2800 & $\begin{array}{r}134 \\
\pm \quad 28\end{array}$ & $\begin{array}{r}4820 \\
\pm 1030\end{array}$ & $\begin{array}{l}\text { Corves } \\
(1992)\end{array}$ \\
\hline $\begin{array}{l}\text { Thalassiosira } \\
\text { punctigera }\end{array}$ & 780 & $\begin{array}{r}60 \\
\pm \quad 6\end{array}$ & $\begin{array}{r}7400 \\
\pm \quad 900\end{array}$ & 8840 & $\begin{array}{r}370 \\
+\quad 75\end{array}$ & $\begin{array}{r}4180 \\
\pm \quad 840\end{array}$ & $\begin{array}{l}\text { Kleinert } \\
(1987)\end{array}$ \\
\hline
\end{tabular}

Dürselen, 1990; Hagmeier, 1991; Aletsee \& Rick, 1990; Aletsee et al., 1992), but there are still periods when this species cannot be found: Hesse (1988) reports high biomasses of $C$. wailesii in spring 1984 in the outer German Bight, while in 1985 only the related native species Coscinodiscus concinnus W. Smith was present. Bauerfeind et al. (1990) observed only Coscinodiscus concinnus in spring 1985 and 1986; C. wailesii is not mentioned. Our 


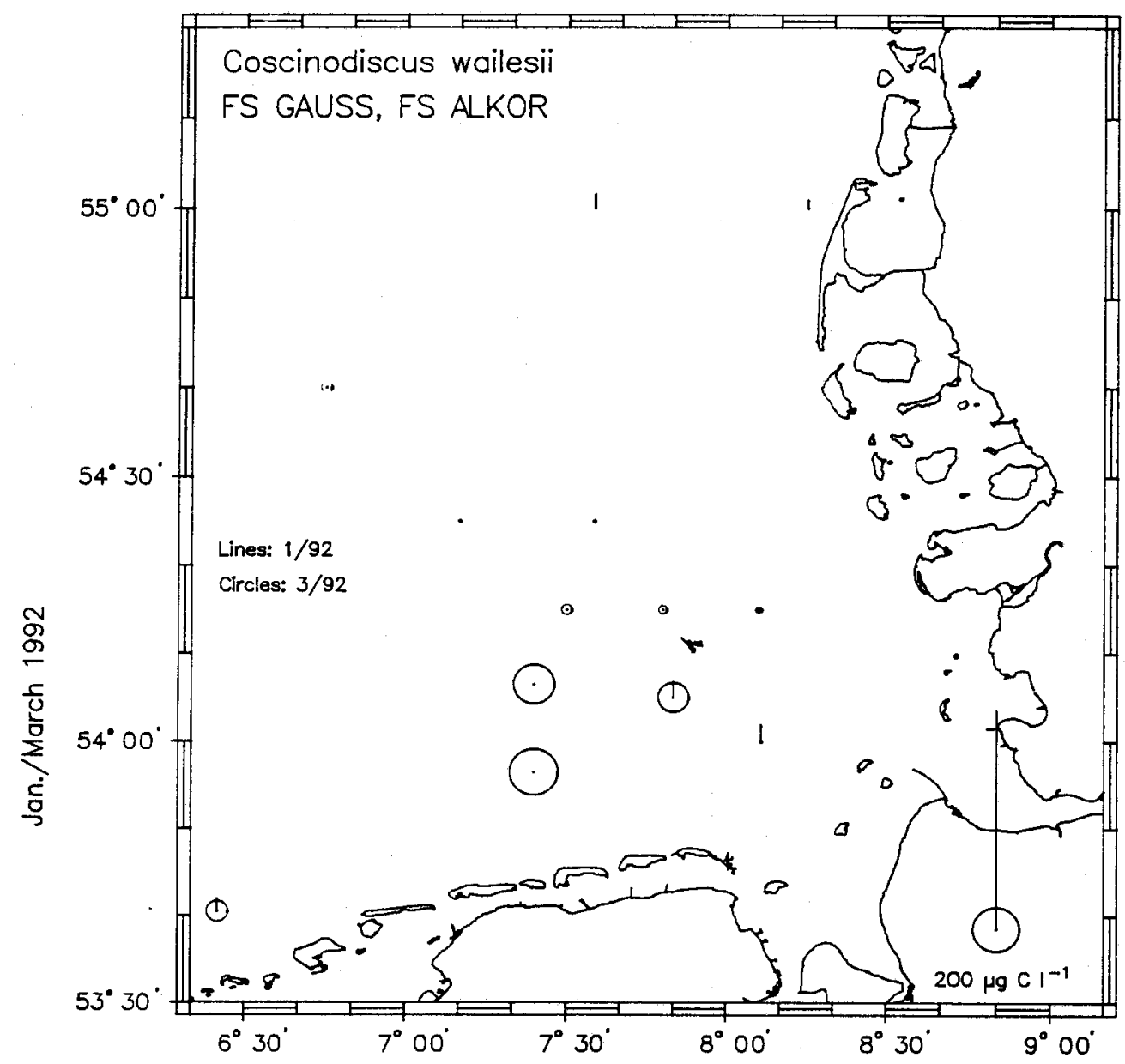

Fig. 6. Spatial distribution and biomass of Coscinodiscus wailesii in the German Bight. Results of two cruises in winter and early spring 1992. The biomass data are given as mean carbon values $(\mu \mathrm{g} C$ $\left.\mathrm{dm}^{-3}\right)$ for the upper layer $(0-20 \mathrm{~m})$ of the water column. Symbol size compares to the biomass value (see legend lower right)

investigations in May 1986 and April 1991 also provided no evidence for the occurrence of $C$. wailesii in the German Bight. These results may lead to the assumption that the appearance of one species may inhibit the occurrence of the other. No evidence for an excluding mechanism can be revealed, on the basis of the data of the PRISMA spring cruise in 1992 (Fig. 7). In this period, both species had identical distribution patterns; only the areas of maximum cell numbers differed. The greater offshore abundance of $C$. concinnus is in accordance to the prediction of Baars (1988), who mentioned deeper water columns and high light regime as growth conditions favoured by $C$. concinnus.

The available 3-year data set shows the distribution features for $C$. wailesii in the area of the German Bight (Figs 2-7). It remains to be seen whether these results describe 


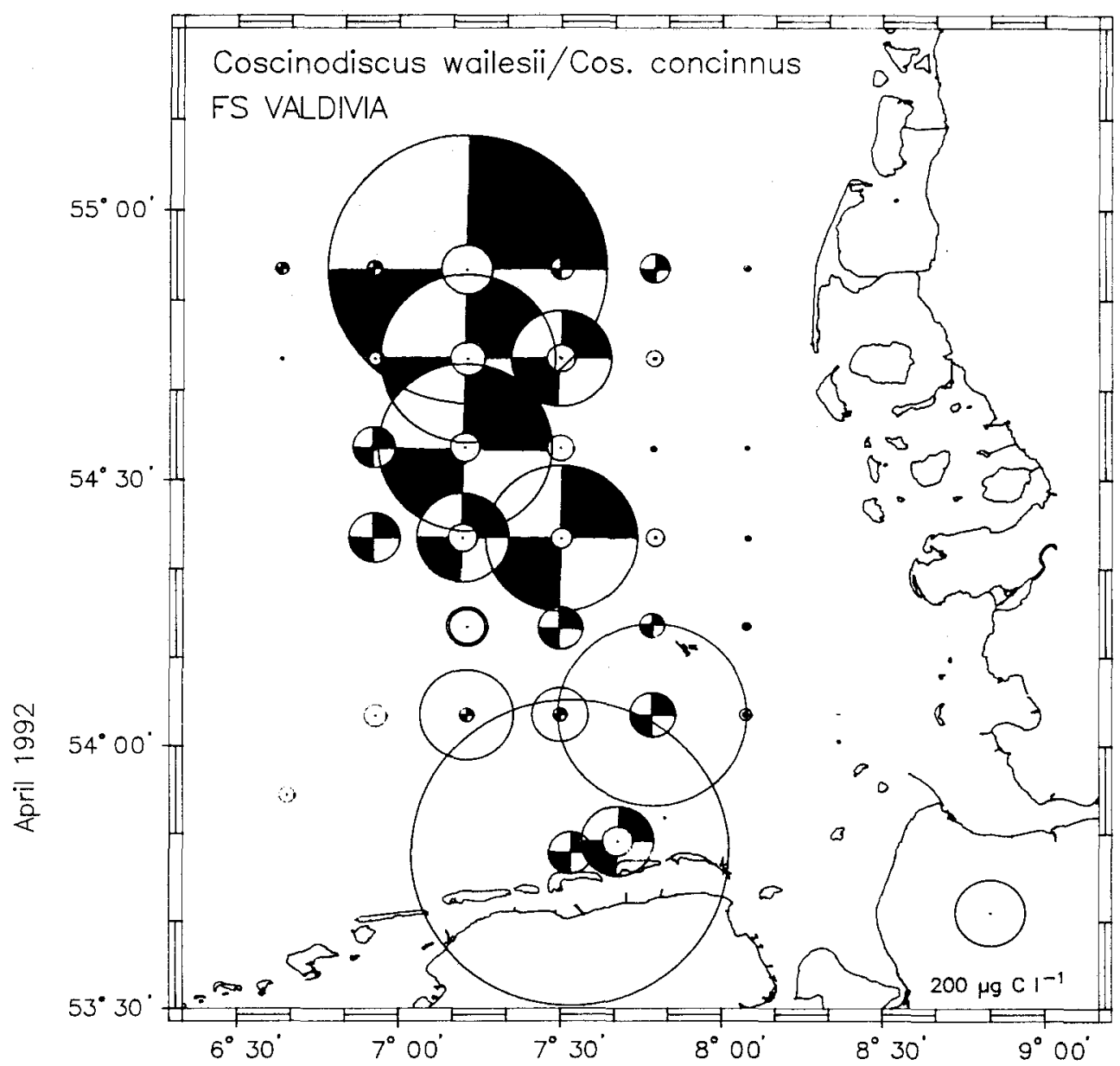

Fig. 7. Spatial distribution and biomass of the introduced Coscinodiscus wailesii and the native Coscinodiscus concinnus in the German Bight during the PRISMA spring cruise in April 1992. The biomass data are given as mean carbon values $\left(\mu \mathrm{g} \mathrm{C} \mathrm{dm}^{-3}\right)$ for the upper layer $(0-20 \mathrm{~m})$ of the water column. Symbol size compares to the biomass value (see legend lower right). $C$. wailesii is displayed by the unfilled circles, $C$. concinnus by the crossed circles

a regular seasonal distribution pattern of the species, since any variability in circulation, light and nutrient regime may have a strong impact on the species' annual development.

Some questions remain to be answered: (1) What are the reasons for the success of Coscinodiscus wailesii in the North Sea area? (2) What is the effect of the spreading of Coscinodiscus wailesii on the ecosystem of the German Bight?

As mentioned before, the species is able to cope with considerable fluctuations of temperature and salinity (Aletsee \& Rick, 1990; Dürselen, 1990) and it also seems to have the ability to handle a wide range of nutrient concentrations (Rince \& Plaumier, 1986). In addition, $C$. wailesii proved to be very tolerant of metals. Field data (Figs 8-11, Table 2) 


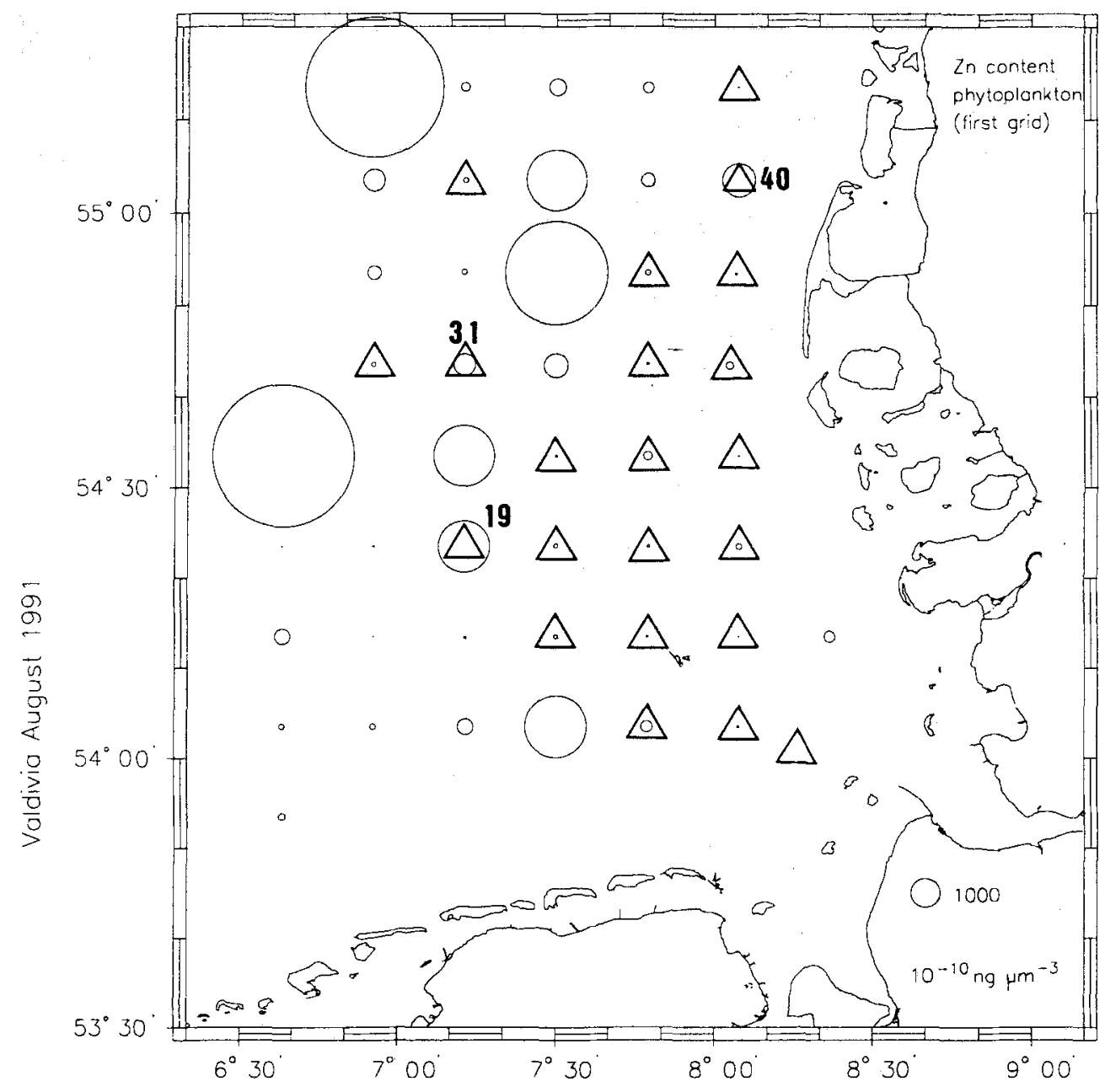

Fig. 8. Spatial distribution of the volume-related zinc content of 50 um net plankton in the German Bight during the PRISMA summer cruise in August 1991. Symbol size compares to the value of the zinc content (see legend lower right). Stations with stock-forming occurrence of $C$, wailesii are marked by unfilled triangles. For numbered stations compare text

and results of laboratory experiments (Table 3) show that, in comparison to native phytoplankton organisms (Table 4), the species bioconcentration of trace metals is low. The bioconcentration factors for zinc measured in field experiments were higher than factors determined in laboratory experiments. This was caused by different concentrations of this metal in the water during field $\left(0.2-0.7 \mu \mathrm{g} \mathrm{zn} \mathrm{kg}^{-1}\right)$ and laboratory experiments (3.0-5.0 $\mu \mathrm{g} \mathrm{Zn} \mathrm{kg}^{-1}$ ). The concentration-dependent metal sorption of the phytoplankton follows the Langmuir isotherm (e.g. Simonis, 1988), a hyperbolic saturation curve. After reaching the curves saturation point, the bioaccumulation declines with rising metal concentration in the water. 


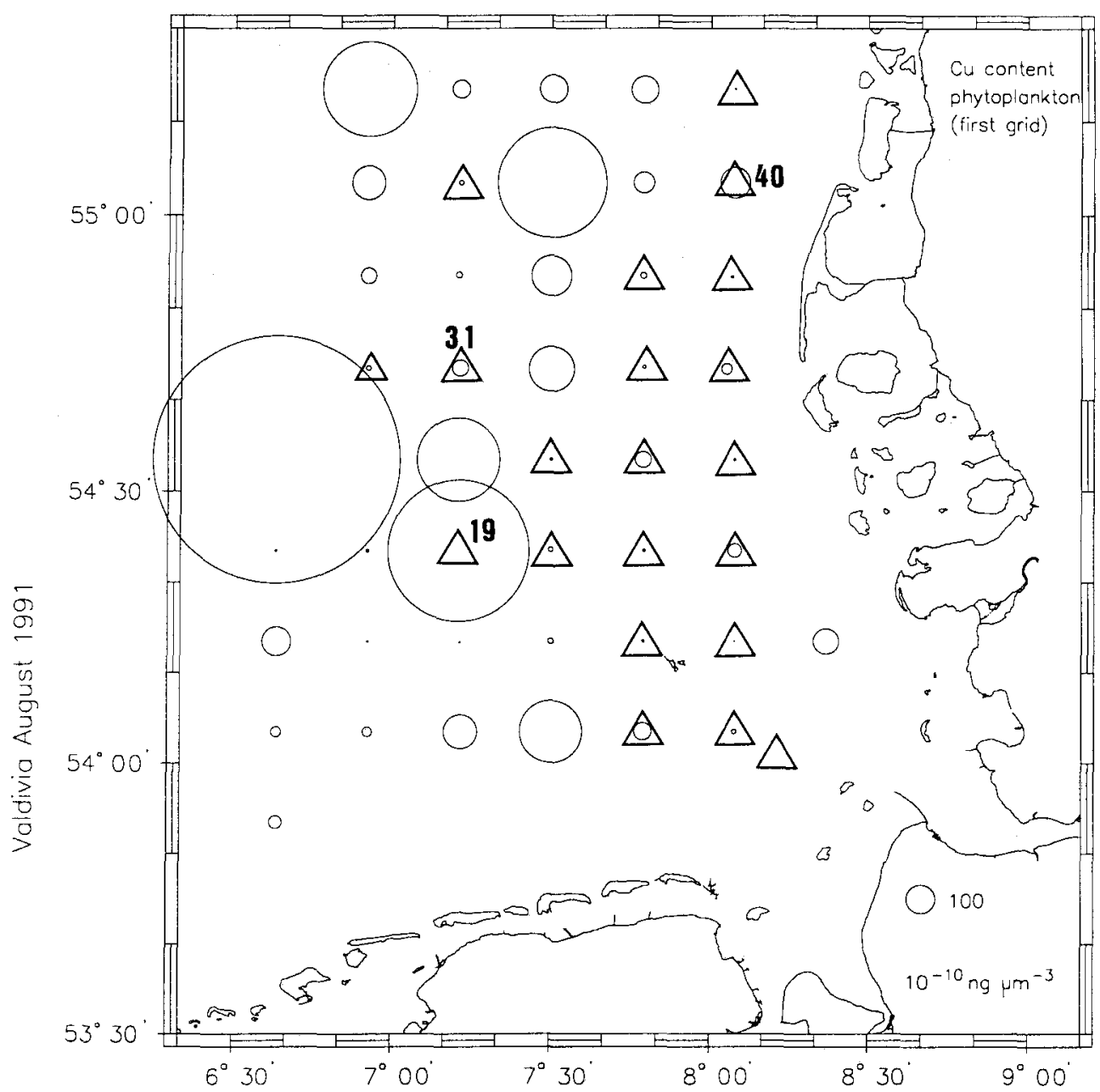

Fig. 9. Spatial distribution of the volume-related copper content of $50 \mu \mathrm{m}$ net plankton in the German Bight during the PRISMA summer cruise in August 1991. Symbol size compares to the value of the copper content (see legend lower right). Stations with stock-forming occurrence of $C$. wailesii are marked by unfilled triangles. For numbered stations compare text

It is unlikely, however, that the high biomass densities of $C$. wailesii during the PRISMA summer cruise (August 1991) were triggered by heavy metal effects, since the measured copper and zinc concentrations in the surrounding water were low (Table 2).

In comparison to native species of similar size, $C$. wailesii displays differing environmental demands. Data won by sampling a grid of 40-50 stations in the German Bight in short time intervals (August 1991) showed no biomass increase for the native Coscinodiscus granii Gough, while $C$. wailesii reached biomass doubling-times comparable to those in laboratory cultures under similar conditions. Simultaneously-monitored nutrient and trace metal levels gave no evidence for nutrient depletion or toxic effects of metals 


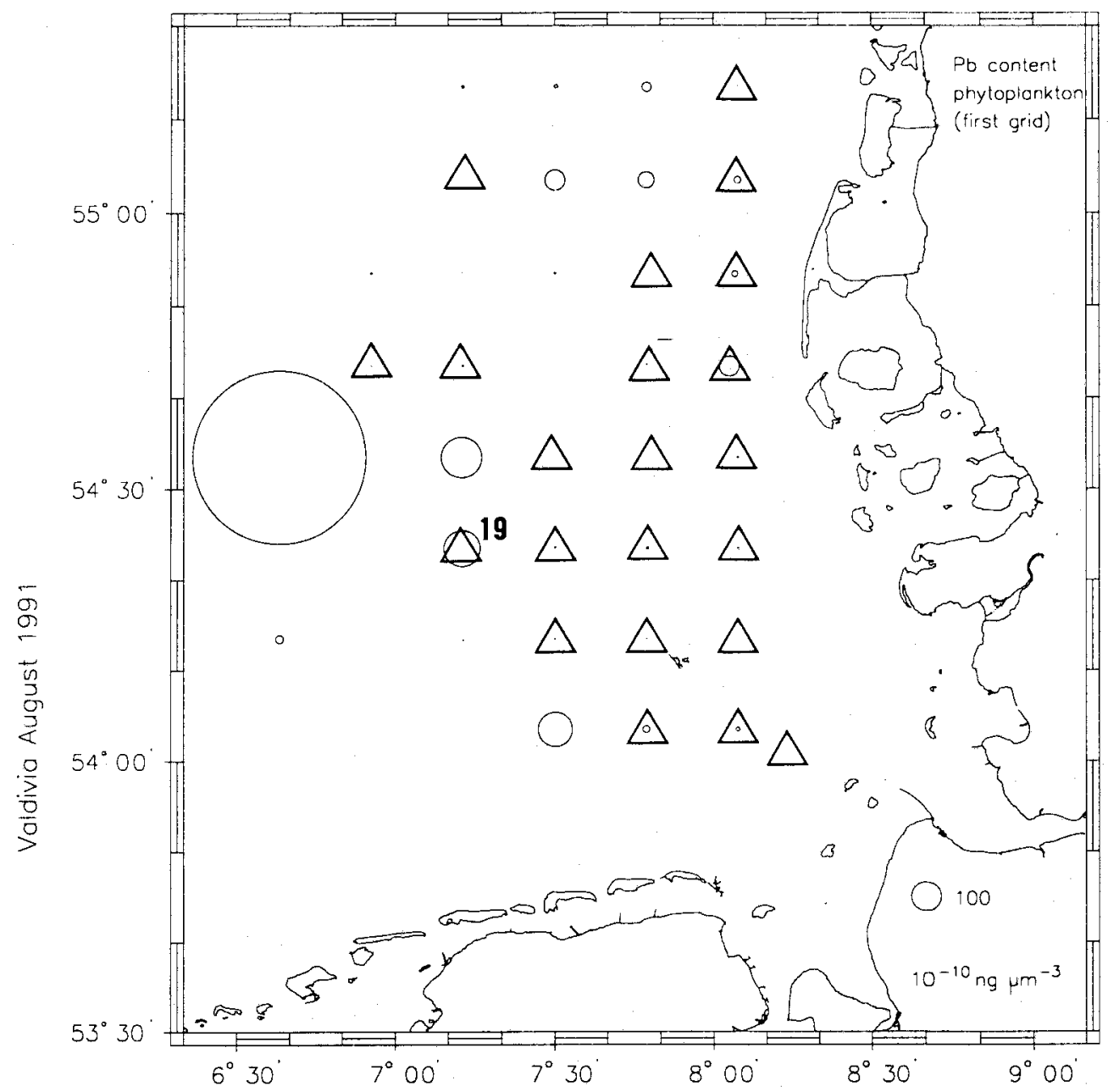

Fig. 10. Spatial distribution of the volume-related lead content of $50 \mu \mathrm{m}$ net plankton in the German Bight during the PRISMA summer cruise in August 1991. Symbol size compares to the value of the lead content (see legend lower right). Stations with stock-forming occurrence of $C$. wailesii are marked by unfilled triangles. For numbered stations compare text

(compare Rabsch \& Elbrächter, 1980) for this campaign period. Maybe a micronutrient that is of lesser importance for the growth of $C$. wailesii than that of $C$. granii was the determining factor.

Experiments conducted by Roy et al. (1989) give another hint for possible reasons for the success of $C$. wailesii. The copepods Temora longicornis O.F.R. Müller and Calanus helgolandicus Claus, both native to the North Sea, showed inefficient or "sloppy" grazing behaviour when raised on $C$. wailesii. Possibly, the primary consumers in the German Bight avoid the ingestion of $C$. wailesii, and the species derives its dominance from this. 


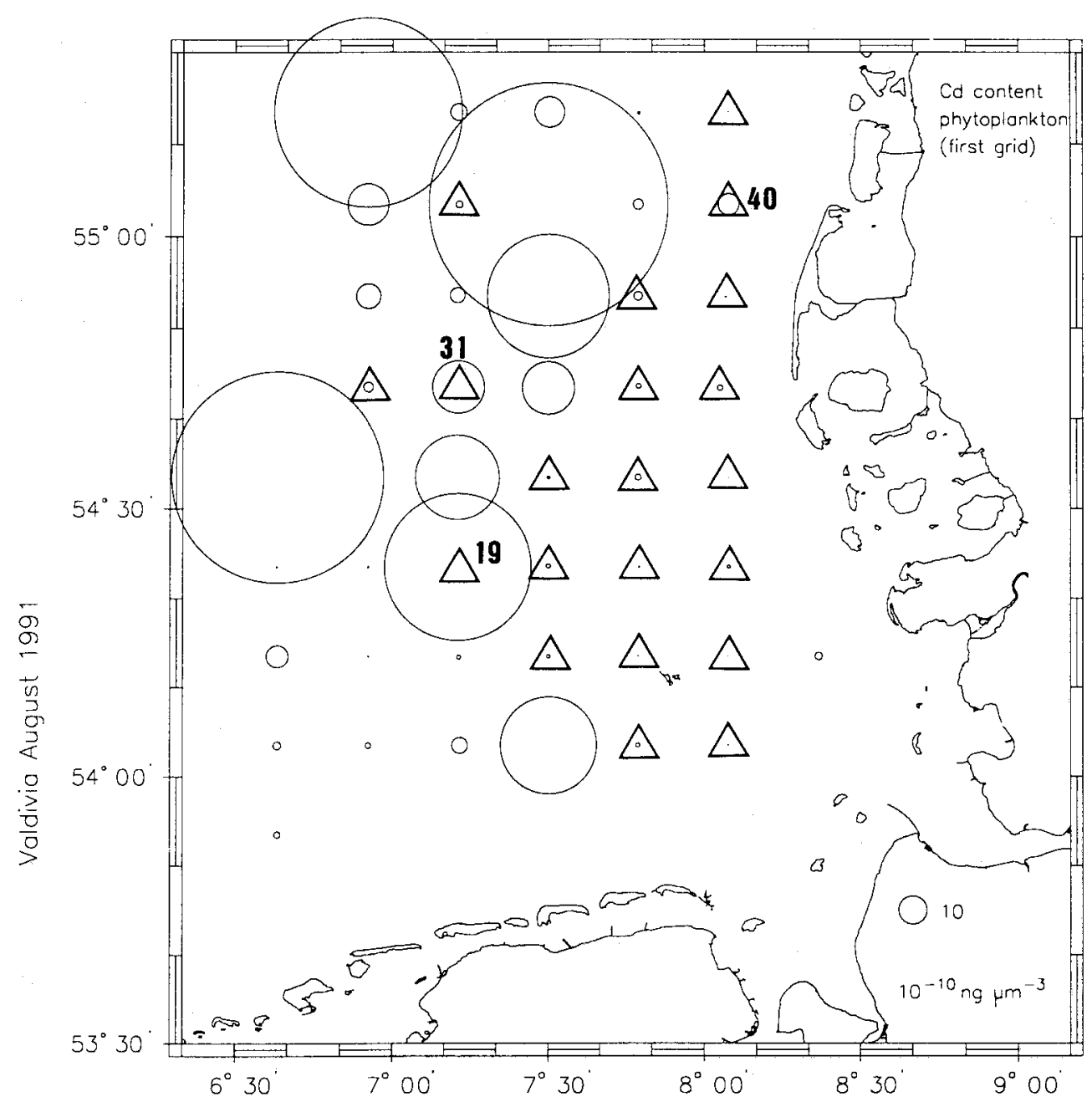

Fig. 11. Spatial distribution of the volume-related cadmium content of 50 um net plankton in the German Bight during the PRISMA summer cruise in August 1991. Symbol size compares to the value of the cadmium content (see legend lower right). Stations with stock-forming occurrence of C. wailesii are marked by unfilled triangles. For numbered stations compare text

The results of three years of research in the German Bight illustrate that $C$. wailesii can supersede native species at times or at least decrease their biomass development. Grazing by copepods may be reduced, and mass development of $C$. wailesii may then have consequences for the following trophic levels.

Prompt sedimentaion of $C$. wailesii resulting from silicate depletion of the water (Manabe \& Ishio, 1991) contributes only a limited amount of carbon remineralisation in the water column. Manabe \& Ishio (1991) studied an autumn bloom of the species in Inland Seto Sea. After sedimentation, the cells were conserved in the bottom mud due to 
low temperatures in winter. In spring, decomposition of the organic components caused oxygen deficits in the bottom water. Consequences of oxygen depletion for benthic organisms are widely known, even for the area of the outer German Bight (v. Westernhagen \& Dethlefsen, 1983; Rachor \& Albrecht, 1983; Rachor, 1985). For the inner German Bight, such eminent outcome is rather unlikely since vertical circulation is initiated frequently by tidal mixing processes.

Acknowledgements. M. Krämer, S. Rick, Dr. U. Tillmann, M. Klerx. V. Bahs, Dr. M. Müller, J. Corves and $\mathrm{H}$. A. Heinz are cordially thanked for their participation in cruises, running laboratory experiments and phytoplankton analysis. Thanks are also due to Dr. M. Haarich (BSH, Hamburg) and his group for phytoplankton sampling in the period September 1991 to March 1992 during TUVAS and OPTINOM programmes. This work was partly financed by the Bundesministerium für Forschung und Technologie under contract Nos. MFU 0545, MFU 0578/7 and O3F0556A.

\section{LITERATURE CITED}

Aletsee, L. \& Rick, H. J., 1990. Phytoplankton. In: Zirkulation und Schadstoffumsatz in der Nordsee. Hrsg. von A. Moll \& G. Radach. Institut für Meereskunde, Univ. Hamburg, Hamburg, Teilprojekt G.5.

Aletsee, L., Rick, H. J., Dürselen, C. D. \& Becker, V., 1992. Schadstoffumsatz im Phytoplankton. In: Prozesse im Schadstoffkreislauf Meer-Atmosphäre: Ökosystem Deutsche Bucht (PRISMA). Hrsg. von J. Sündermann \& S. Beddig. Zentrum für Meeres- und Klimaforschung, Univ. Hamburg, Hamburg, 2, 168-178.

Baars, J. W. M., 1988. Autecological investigations on marine diatoms. 5: Coscinodiscus concinnus W. Smith and Rhizosolenia setigera Brightwell. - Hydrobiol. Bull. 22, 147-155.

Bauerfeind, E., Hickel, W., Niermann, U. \& Westernhagen, H. von, 1990. Phytoplankton biomass and potential limitation of phytoplankton development in the southeastern North Sea in spring 1985 and 1986. - Neth. J. Sea Res. 25, 131-142.

Boalch, G. T. \& Harbour, D. S., 1977 a. Unusual diatom off the coast of south-west England and its effect on fishing. - Nature, Lond. 269, 687-688.

Boalch, G. T. \& Harbour, D. S., 1977b. The structure of the valve and girdle of a planktonic Pleurosigma. - Nova Hedwigia (Beih.) 54, 275-280.

Corves, J., 1992. Untersuchungen zur Schwermetallbelastung des Sommerphytoplanktons in der Deutschen Bucht mit ergänzenden Laborexperimenten zur Interpretation der Ergebnisse. Dipl.Arb., TH Aachen, 129 pp.

Cupp, E. E., 1943. Marine plankton diatoms of the west coast of North America. - Bull. Scripps Instn Oceanogr. 5, 1-238.

Drebes, G., 1991. Neue Planktondiatomeen im Sylter Wattenmeer. - Jber. Biol. Anst. Helgoland 1990, 29-30.

Dürselen, C. D., 1990. Untersuchungen zur Schwermetallakkumulation von Phytoplanktongemeinschaften der Deutschen Bucht mit ergänzenden Laborversuchen zur Deutung der Ergebnisse. Dipl-Arb., TH Aachen, 127 pp.

Gerlach, S., 1992. Ergebnisse der 5. Internationalen Konferenz über giftiges marines Phytoplankton. DGM Mitt. 2/1992, 5-11.

Gotelli, D., 1971. Lagenisma coscinodisci, a parasite of the marine diatom Coscinodiscus occurring in the Puget sound, Washington. - Mycologica 63, 171-174.

Gran, H. H. \& Angst, E. C., 1931. Plankton diatoms of the Puget sound. - Publs Puget Sound mar. biol. Stn 7, 417-516.

Guo Yujie, 1981. Studies on the planktonic Coscinodiscus of the South Chinas Sea. - Stud. mar. sin. $18,149-175$.

Hagmeier, E., 1991. Phytoplankton bei Helgoland im Sommer 1990. - Jber. Biol. Anst. Helgoland $1990,43-44$.

Hesse, K.-J., 1988. Zur Ökologie des Phytoplanktons in Fronten und Wassermassen der Deutschen Bucht. Diss., Univ. Kiel, 153 pp. 
Kat, M., 1982. Effects of fluctuating salinities on the development of Thalassiosira angstii, a diatom not observed before in the Dutch coastal area. - J. mar, biol. Ass. U.K. 62, 483-484.

Kleinert, R., 1987. Laboruntersuchungen zur Beeinflussung der Assimilationsleistung von Phaeocystis globosa Scherffel und Thalassiosira punctigera Castr. durch die Schwermetalle Kupfer, Zink, Quecksilber und Cadmium. Dipl.-Arb., TH Aachen, 158 pp.

Mahoney, J. B. \& Steimle, F. W., 1980. Possible association of fishing gear clogging with a diatom bloom in the middle Atlantic Bight. - Bull. New Jers. Acad. Sci. 25, 18-21.

Manabe, T. \& Ishio, S., 1991. Bloom of Coscinodiscus wailesii and DO deficit of bottom water in the Seto Inland Sea. - Mar. Pollut. Bull. 23, 181-184.

Marshall, H. G., 1984. Phytoplankton distribution along the eastern coast of the USA. V: Seasonal density and cell volume pattern for the north eastern continental shelf. - J. Plankton Res. 6 , $169-193$.

Mart, L., 1979a. Prevention of contamination and other accuracy risks in voltammetric trace metal analysis of natural waters. I: Preparatory steps, filtration and storage of water samples. Fresenius Z. analyt. Chem. 296, 350-357.

Mart, L., 1979b. Prevention of contamination and other accuracy risks in voltammetric trace metal analysis of natural waters. II: Collection of surface water samples. - Fresenius Z. analyt. Chem. $299,97-102$.

Mart, L., 1979c. Ermittlung und Vergleich des Pegels toxischer Spurenmetalle in nordatlantischen und mediterranen Küstengewässern. Diss., TH Aachen, 354 pp.

Mart, L., 1982. Minimization of accuracy risks in Voltammetric ultratrace determination of heavy metals in natural waters. - Talanta 29, 1035-1040.

Mart, L., Nürnberg, H. W. \& Valenta, P., 1980. Prevention of contamination and other accuracy risks in voltammetric trace metal analysis of natural waters. III. Voltammetric ultratrace analysis with a multicell system designed for Clean Bench Working. - Fresenius Z. analyt. Chem. 300, 350-362.

Navarro, J. N., 1982. A survey of the marine diatoms of Puerto Rico. I. Suborders Coscinodiscineae and Rhizosoleniineae. - Botanica mar. 24, 427-439.

Ostenfeld, C. H., 1908. On the immigration of Biddulphia sinensis Grev. and its occurrence in the North Sea during 1903-1907. - Meddr Kommn Havunders. (Plankton) 1 (6), 1-44.

Ostenfeld, C. H., 1909. Immigration of a plankton diatom into a quite new area within recent years; Biddulphia sinensis in the North Sea waters. - Int. Revue ges. Hydrobiol. Hydrogr. 2, 362-374.

Patten, B. C., Mulford, R. A. \& Warriner, J. E., 1963. An annual phytoplankton cycle in the lower Chesapeake Bay. - Chesapeake Sci. 4, 1-20.

Rabsch, U. \& Elbrächter, M., 1980. Cd and Zn uptake, growth and primary production in Coscinodiscus granii cultures containing low levels of cells and dissolved organic carbon. - Mar. Ecol. Prog. Ser. 14, 275-285.

Rachor, E. \& Albrecht, H., 1983. Sauerstoffmangel im Bodenwasser der Deutschen Bucht. - Veröff. Inst. Meeresforsch. Bremerh. 19, 209-227.

Rachor, E., 1985. Eutrophierung in der Nordsee - Bedrohung durch Sauerstoffmangel. - Abh. naturwiss. Ver. Bremen 40, 283-292.

Rick, H.-J., 1990. Ein Beitrag zur Abschätzung der Wechselbeziehung zwischen den planktischen Primärproduzenten des Nordseegebietes und den Schwermetallen Kupfer, Zink, Cadmium und Blei auf der Grundlage von Untersuchungen an natürlichen Planktongemeinschaften und Laborexperimenten mit bestandsbildenden Arten. Diss., TH Aachen, 330 pp.

Rince, Y. \& Plaumier, G., 1986. Données nouvelles sur la distribution de la diatomée marine Coscinodiscus wailesii Gran \& Angst (Bacillariophyceae). - Phycologia 25, 73-79.

Robinson, G. A., Budd, T. D., John, A. W. G. \& Reid, P. C., 1980. Coscinodiscus nobilis (Grunow) in continuous plankton records, 1977-1978. - J. mar. biol. Ass. U.K. 60, 675-680.

Roy, S., Harris, R. P. \& Poulet, S. A., 1989. Inefficient feeding by Calanus helgolandicus and Temora longicornis on Coscinodiscus wailesii: quantitative estimation using chlorophyll-type pigment and effects on dissolved free amino acids. - Mar. Ecol. Prog. Ser. 52, 145-153.

Simonis, W., 1987. Primärvorgänge bei der Sorption von Schwermetallen, Insektiziden und Herbiziden in die Anfangsglieder von Nahrungsketten. In: Bioakkumulation in Nahrungsketten. Hrsg. von K. I.illelund, U. de Haar, H.-J. Elster, L. Karbe, I. Schwoerbel \& W. Simonis. VCH, Weinheim, 9-38.

Stosch, H. A. von \& Drebes, G, 1964. Entwicklungsgeschichtliche Untersuchungen an zentrischen 
Diatomeen. IV. Die Planktondiatomee Stephanopyxis turris, ihre Behandlung und Entwicklungsgeschichte. - Helgoländer wiss. Meeresunters. 11, 209-257.

Strickland, J. D. H. \& Parsons, T. R., 1972. A practical handbook of seawater analysis. - Bull. Fish. Res. Bd Can. 167, 1-310.

Tangen, K., 1977. Blooms of Gyrodinium aureolum in north European waters, accompanied by mortality in marine organisms. - Sarsia 63, 123-133.

Westernhagen, H. von \& Dethlefsen, V., 1983. North Sea oxygen deficiency 1982 and its effects on the bottom fauna. - Ambio 12, 264-266. 